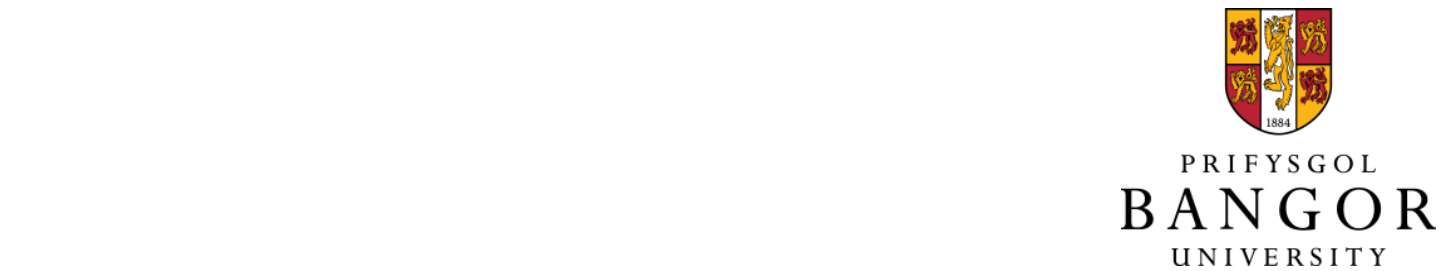

\title{
M11A randomised controlled feasibility trial of a physical activity behaviour change intervention compared to social interaction in huntington's disease
}

Busse, Monica; Quinn, Lori; Drew, Cheney; Kelson, Mark; Trubey, Rob; McEwan, Kirsten; Jones, Carys; Townson, Julia; Dawes, Helen; Edwards, Rhiannon; Rosser, Anne; Hood, Kerenza

Journal of Neurology, Neurosurgery and Psychiatry

DOI:

10.1136/jnnp-2016-314597.296

Published: 01/09/2016

Peer reviewed version

Cyswllt i'r cyhoeddiad / Link to publication

Dyfyniad o'r fersiwn a gyhoeddwyd / Citation for published version (APA):

Busse, M., Quinn, L., Drew, C., Kelson, M., Trubey, R., McEwan, K., Jones, C., Townson, J., Dawes, H., Edwards, R., Rosser, A., \& Hood, K. (2016). M11A randomised controlled feasibility trial of a physical activity behaviour change intervention compared to social interaction in huntington's disease. Journal of Neurology, Neurosurgery and Psychiatry, 87(Suppl 1), A105. https://doi.org/10.1136/jnnp-2016-314597.296

\footnotetext{
Hawliau Cyffredinol / General rights

Copyright and moral rights for the publications made accessible in the public portal are retained by the authors and/or other copyright owners and it is a condition of accessing publications that users recognise and abide by the legal requirements associated with these rights.

- Users may download and print one copy of any publication from the public portal for the purpose of private study or research.

- You may not further distribute the material or use it for any profit-making activity or commercial gain

- You may freely distribute the URL identifying the publication in the public portal ?
}

Take down policy

If you believe that this document breaches copyright please contact us providing details, and we will remove access to the work immediately and investigate your claim. 


\title{
M11 A RANDOMISED CONTROLLED FEASIBILITY TRIAL OF A PHYSICAL ACTIVITY BEHAVIOUR CHANGE INTERVENTION COMPARED TO SOCIAL INTERACTION IN HUNTINGTON'S DISEASE
}

\author{
${ }^{1,2}$ Monica Busse*, ${ }^{1,3}$ Lori Quinn, ${ }^{2}$ Cheney Drew, ${ }^{2}$ Mark Kelson, ${ }^{2}$ Rob Trubey, ${ }^{2}$ Kirsten McEwan, ${ }^{4}$ Carys \\ Jones, ${ }^{2}$ Julia Townson, ${ }^{5}$ Helen Dawes, ${ }^{4}$ Rhiannon Tudor Edwards, ${ }^{6}$ Anne Rosser, ${ }^{3}$ Kerenza Hood. \\ 1 School of Healthcare Sciences, Cardiff University, Eastgate House, Cardiff, UK; \\ 2 South East Wales Trials Unit, Centre for Trials Research, Cardiff University, Heath Park, Cardiff, UK; \\ 3 Department of Biobehavioral Sciences, Teachers College, Columbia University, USA; \\ 4 Centre for Health Economics and Medicines Evaluation, Bangor University, Bangor, India; \\ 5 Oxford Institute of Nursing and Allied Health Research, Oxford Brookes University, Oxford, UK; \\ 6 Schools of Medicine and Biosciences, Cardiff University, Cardiff, UK
}

\section{Background}

Regular physical activity has health benefits for people with Huntington's disease (HD), however consistent engagement is challenging. We report the results of a single blind, multisite, randomised controlled feasibility trial of a physical activity intervention in HD.

\section{Methods}

Participants were randomly assigned to physical activity or social contact control interventions. The primary outcome was feasibility. Short-term benefit was assessed with the Physical Performance Test (PPT), a measure of functional ability. A range of exploratory outcomes including home and community mobility (Life Space), self-efficacy (Lorig), physical activity (International Physical Activity Questionnaire (IPAQ)), as well as disease-specific measures of motor and cognitive function were evaluated. Intervention fidelity and delivery costs were established. The trial was registered (ISRCTN $65378754(13 / 03 / 2014))$.

\section{Results}

We recruited 46 people with HD; 22 were randomised to the physical intervention ( $n=16$ analysed); 24 to social contact ( $n=22$ analysed). Retention, fidelity and adherence met predetermined criteria. IPAQ scores in the physical intervention group were $142 \%$ higher (1.42; 95\% CI: [22\%\%, 653\%]); and self-efficacy for exercise $(1.6 ; 95 \% \mathrm{Cl}$ : $[0.6,2.7])$ was also higher. Life Space scores were 12 points different between groups; $95 \% \mathrm{Cl}:[2,27]$. Cognitive function was better in the physical intervention group with 2.9 more correct responses (95\% Cl: $[0.01,5.9])$ on the Symbol Digit Modality test. There were no differences in other exploratory outcome measures and in particular no between-group differences in the PPT (treatment effect: $0.3,95 \% \mathrm{Cl}:[2.1,2.7])$. Mean (SD) physical intervention per session cost was $£ 56.97$ ( $£ 34.72$ ).

\section{Conclusion}

A physical activity coaching intervention is feasible, can improve self-efficacy, physical activity behaviours and cognitive function in people with HD and represents excellent value for money in a devastating disease.

\section{Funding}

Health and Care Research Wales. 